Milan Radovanović

Universiteit van Belgrado

https://doi.org/10.18485/bgd_nlistiek_30.2018.ch14

\title{
NEDERLANDSE STEUN IN DE PERIODE 1916-1918 AAN DE KRIJGSGEVANGEN EN GEİNTERNEERDE SERVIËRS IN DUITSLAND EN OOSTENRIJK-HONGARIJE
}

\section{Voorwoord}

Enige tijd geleden ontving ik het boek “Twee miljoen pakketten"geschreven, door Hans van Lith. Het boek geeft inzicht in de indrukwekkende hulp die door particulier initiatief vanuit het neutrale Nederland werd geboden aan krijgsgevangenen en geïnterneerden in de Eerste Wereldoorlog. Er werd bij het bieden van deze hulp geen onderscheid gemaakt tussen de strijdende partijen. Hieruit blijkt dat ook Serviërs pakketten in deze kampen ontvingen. Hierover was weinig tot niets bekend. Dat vanuit Nederland naar gevangen en geïnterneerde Serviërs in kampen in de OostenrijksHongaarse dubbelmonarchie en Duitsland ruim 47.000 pakketten zijn verzonden, was voldoende reden voor nader onderzoek.

\section{Inleiding}

Het Servische leger werd in de herfst van 1915 door een grote overmacht van Duitse, Oostenrijk-Hongaarse en Bulgaarse troepen gedwongen zich door de bergen terug te trekken naar Albanië en Montenegro. De militaire steun van de geallieerden was minimaal. In de gevechten werden grote aantallen Servische soldaten gevangen genomen(zie afb.1 en 2).De bevolking van Servië werd door de bezetters geïntimideerd en onder druk gezet en alle mannen tussen 17 en 55 jaar die niet in het leger zaten werden in kampen ondergebracht. Alleen al op het grondgebied van Kroatië, Vojvodina en Bosnië Herzegovina waren er, behalve de permanente (deze worden later in de tekst genoemd), 20 tijdelijke kampen gebouwd. De geïnterneerden werden zeer slecht gevoed, waren verstoken van medische zorg, moesten zwaar werk verrichten, werden gemarteld en om het geringste vergrijp vermoord. 


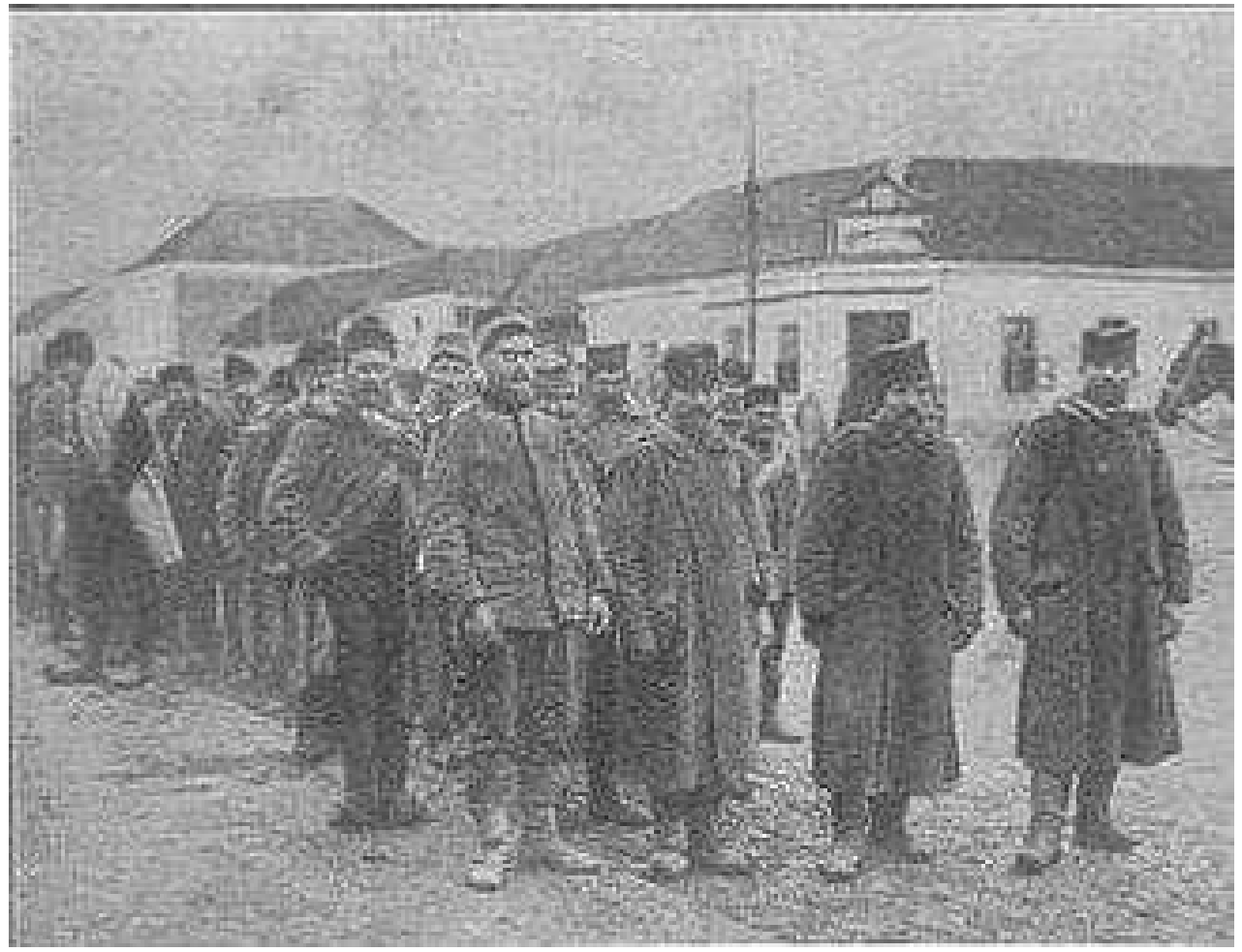

Afbeelding 1: Serviërs die in Belgrado gevangen werden genomen uit de Kroatische 'Ilustrovani list' No.95, foto ca. 1915.

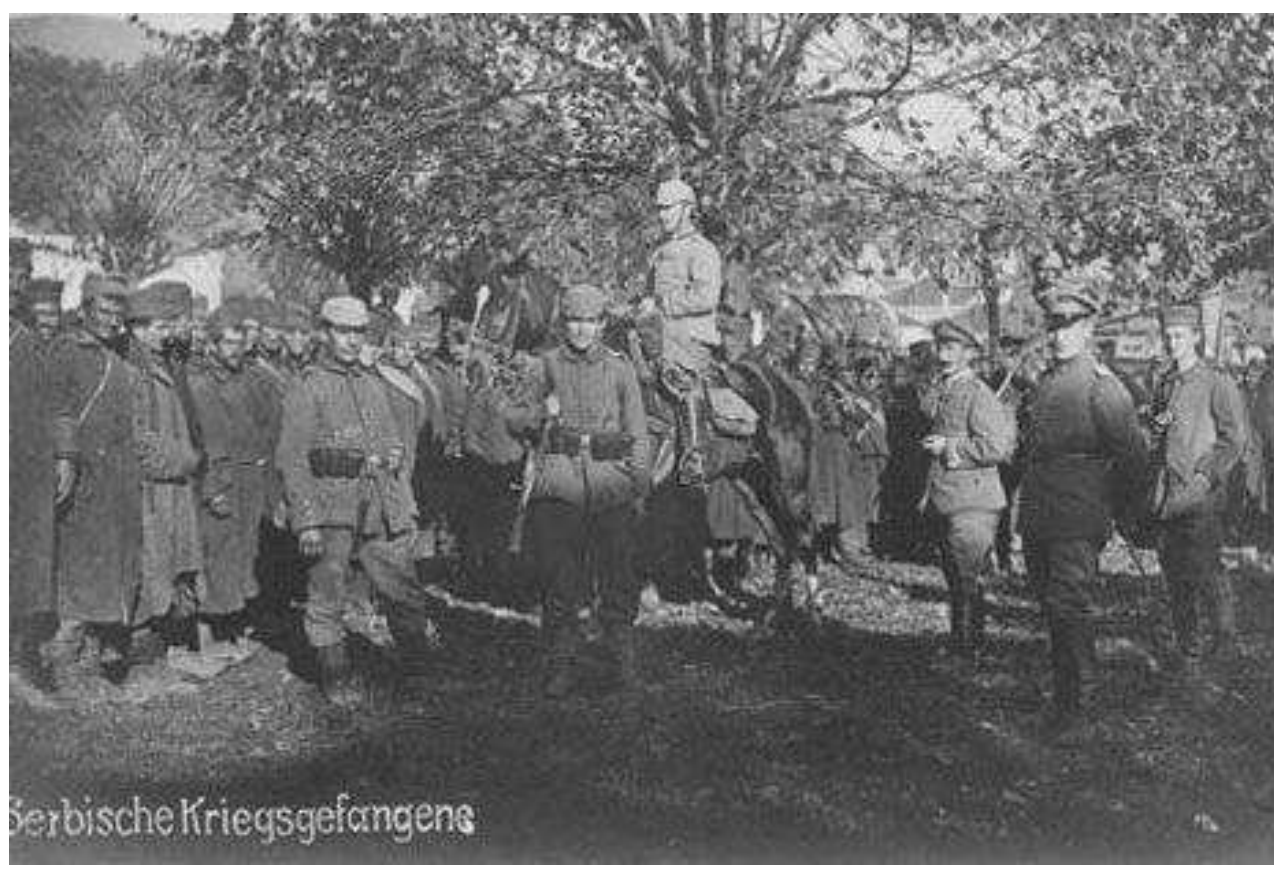

Afbeelding 2: Duitse prentbriefkaart 'Serbische Kriegsgefangene'.

Velen hebben het niet overleefd. Zo is bijvoorbeeld vanuit het kamp Arad na de oorlog maar eenvijfde deel van het aantal geïnterneerde Serviërs teruggekeerd. Volgens de huidige schattingen bedroeg het aantal geïnterneerde burgers tussen de 150.000 200.000 (Radojevič \& Dimić 2014). 


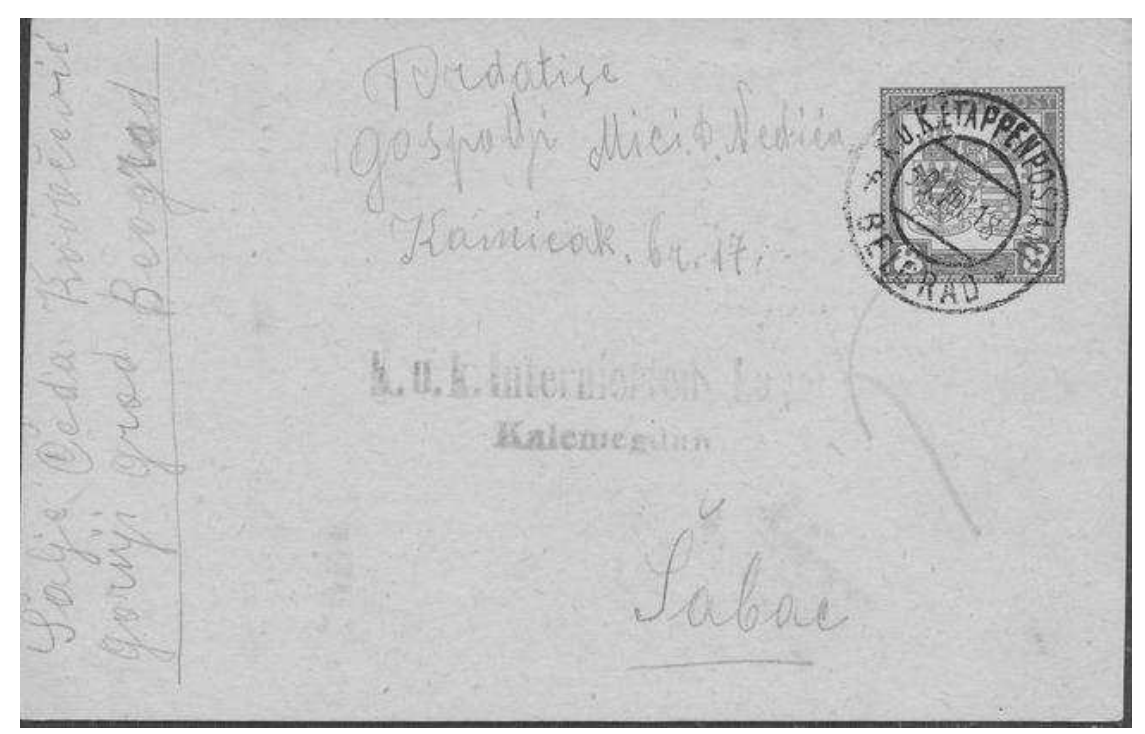

Afbeelding 3: Postwaardestuk, verzonden van Belgrado naar het 'K.u.K. Internierung Kamp Kalemegdan' in Sabac, een tijdelijk kamp (collectie H.Dietz).

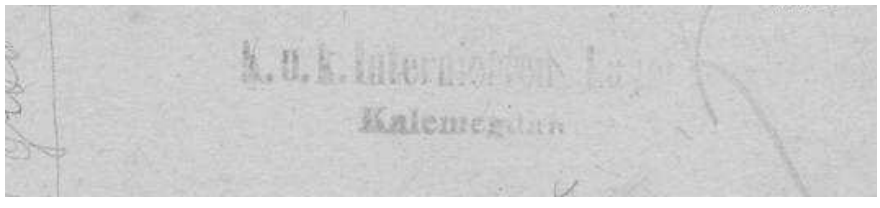

Afbeelding 4: Stempel 'K.u.K. Internierung Kamp Kalemegdan.'

De harde realiteit van het leven in deze kampen is te zien op een Franse liefdadigheidskaart (zie Afbeelding 5).

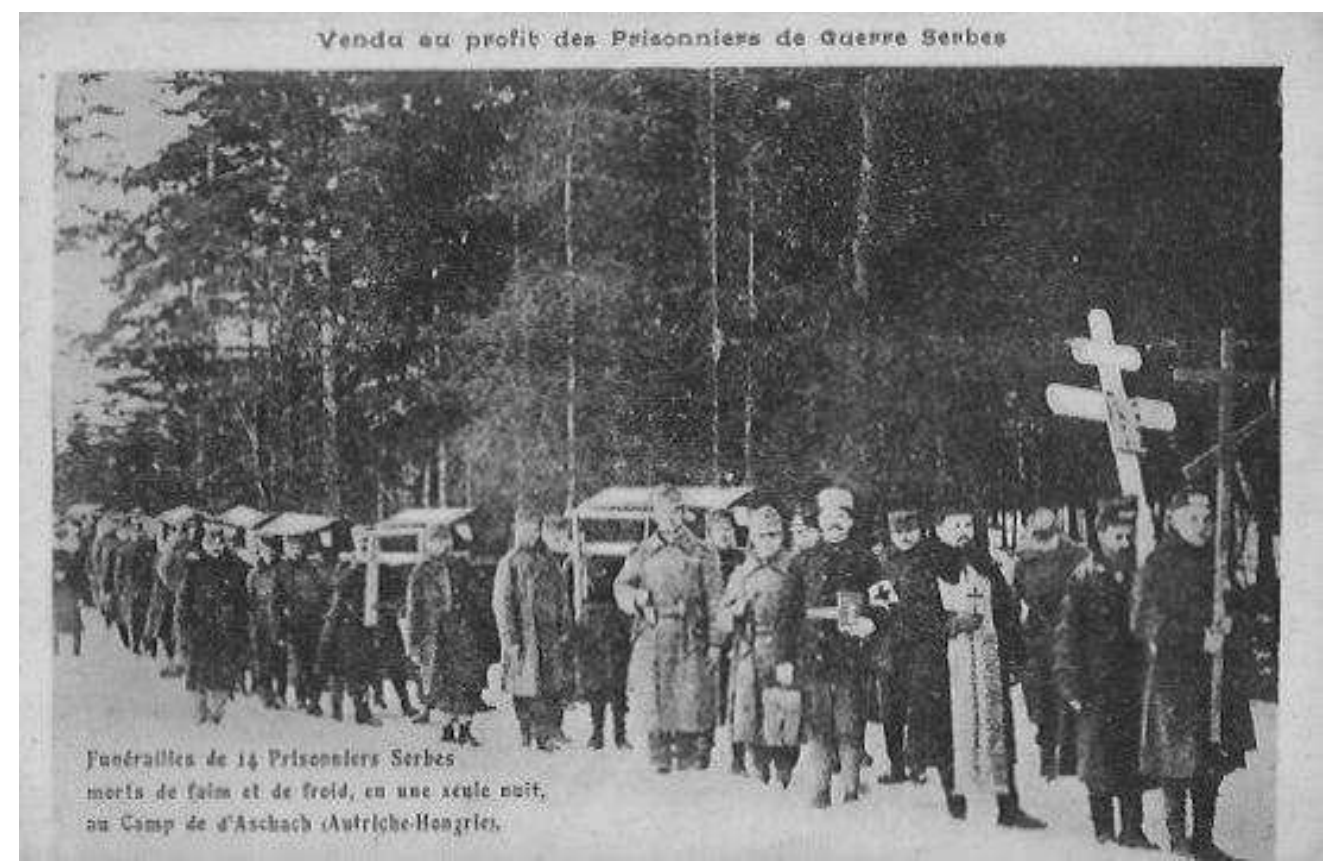

Afbeelding 5: 'Begrafenis van 14 Servische krijgsgevangenen die van honger en kou na een enkele nacht in het kamp Aschach in het Oostenrijks-Hongaarse Rijk zijn gestorven'. Deze Franse prentbriefkaart werd verkocht ter ondersteuning van de Servische gevangenen ('Vendu au profit des Prisonnières de GuerreSerbes'). 


\section{Ontstaan van de Vereniging 'Liefdewerk'}

$\mathrm{Na}$ een aantal individuele initiatieven werd op 15 februari 1915 door een groepje invloedrijke mensen in Maastricht de vereniging 'Internationaal liefdewerk voor Gewonden en Krijgsgevangenen' opgericht. Deze had tot doel het leed van de geïnterneerden en krijgsgevangenen in de kampen van de oorlogvoerenden te verzachten, ongeacht hun nationaliteit. Drijvende kracht was gravin De Geloes-De Lanoy, echtgenote van de burgemeester van Eijsden. Zij werd voorzitter (Lith 2011:55).

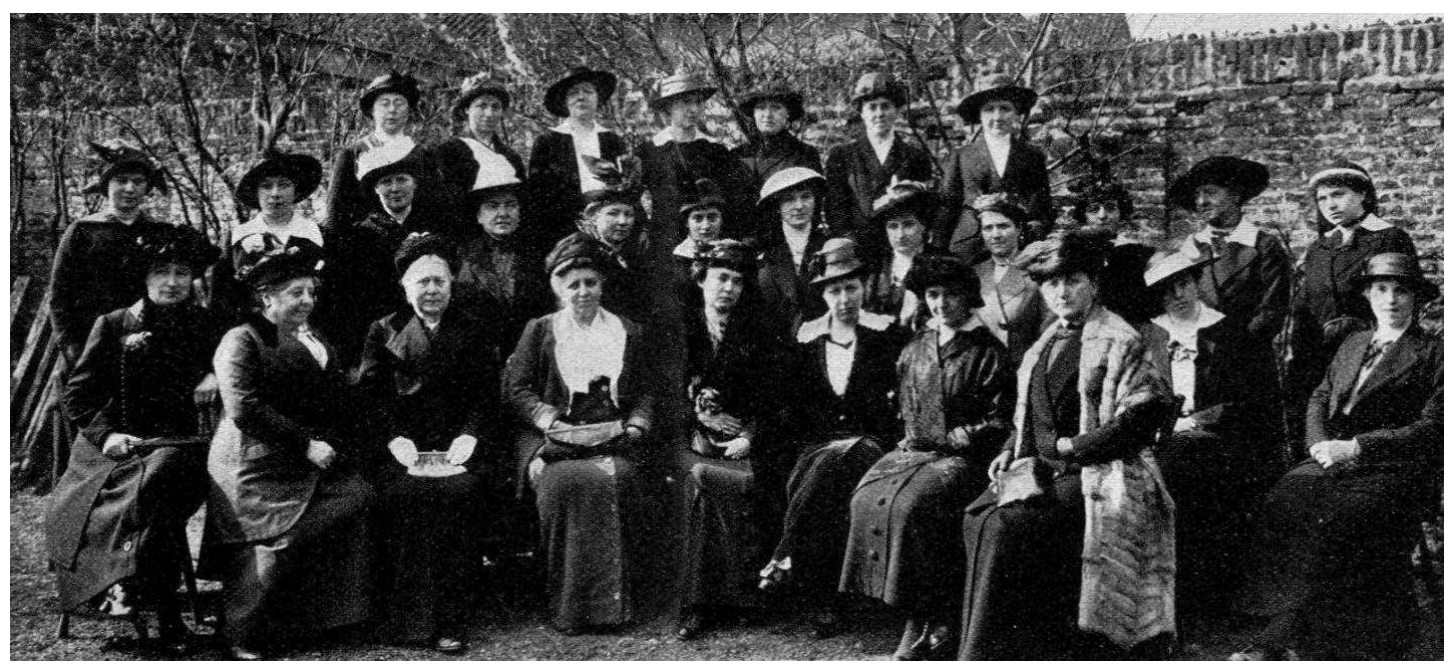

Afbeelding 6: Bestuur en leden van het Centraal Comité voor het Internationaal Liefdewerk voor Gewonden en Krijgsgevangenen. Op de eerste rij, derde van links en verder: vicepresidente mevr. Regout, presidente Blanche gravin de Geloes-van Lannoy, vice-presidente mevr. Driebeek, secretaresse gravin De Liedekerke, secretaresse 2de afdeling mevr. Hansen, penningmeester mevr. Seydlitz.

De belangrijkste doelstelling van het comité was 'hulp verlenen aan krijgsgewonden en -gevangenen in het algemeen en vooral de zulken die verlaten zijn en geen betrekking met hunne familie hebben, of wier familie te arm is, om hen te helpen' (Lith 2011:2021).

In de eigentijdse Servische literatuur is er slechts één vermelding over gravin De Geloes te vinden, namelijk in de memoires van de Servische ambassadeur in Nederland M.Milojević (Milojević 1994). Vrij vertaald: 'Toen ik in Den Haag aankwam werd ik geïnformeerd over de activiteiten van de edele gravin De Geloes....... zodra ik gereed was met de officiële taken ging ik met mijn vrouw naar de gravin. Dit was ons eerste bezoek aan een Nederlandse familie. De gravin was blij met ons bezoek. Wij werden hartelijk ontvangen, zij was buitengewoon geïnteresseerd in het lijden van ons volk. Mijn vrouw en ik waren aangenaam verrast door het enthousiasme van deze oudere dame om een klein land, dat zo'n grote slag heeft doorgemaakt, te willen helpen. Bij ons afscheid heb ik haar namens de regering van het Koninkrijk Servië bedankt en ook persoonlijk voor alles wat ze voor onze gevangenen deed. Haar antwoord was dat zij alles zou blijven doen wat ze kon, samen met haar vrienden.' 


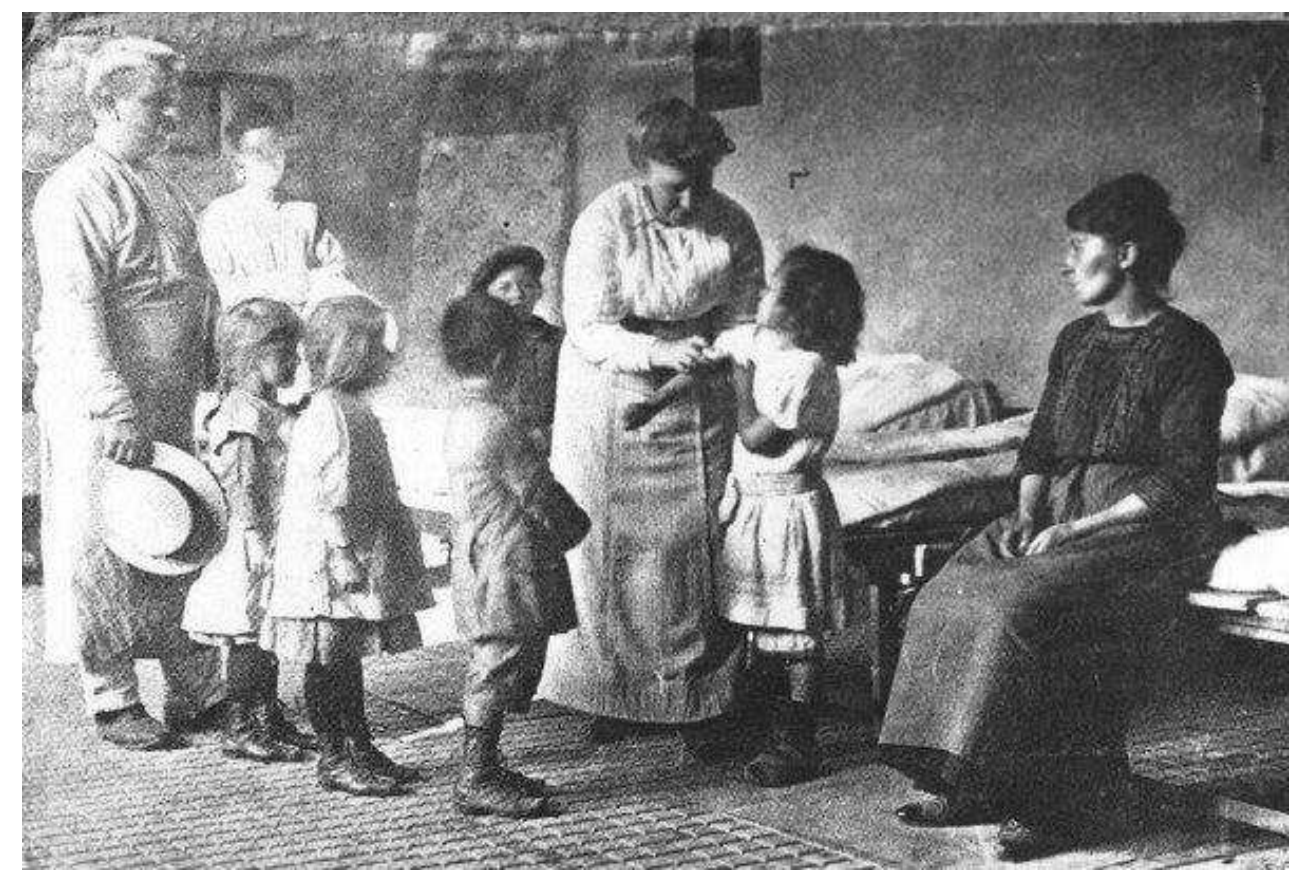

Afbeelding 7: Gravin De Geloes zorgt voor Belgische kinderen - oorlogsvluchtelingen (uit van der Steen).

De vereniging stuurde geld, levensmiddelen, kleding, schoenen, rookwaren en andere zaken die de kampbewoners nodig hadden, ongeacht hun politieke overtuiging, religie of nationaliteit.

Het werd de vrijwilligers niet altijd gemakkelijk gemaakt.Er waren door de oorlogsomstandigheden problemen met in- en exportformaliteiten, fondsenwerving, kosten voor de verzending van pakketten, belasting, controle op het vervoer enz. Een groter probleem was echter, dat het bestuur van het Nederlandse Rode Kruis hen als 'bedreiging' (lees: concurrent) zag en de vereniging onder haar gezag wilde brengen. Dat heeft nogal wat discussies en strijd opgeleverd, omdat de medewerkers van gravin De Geloes veel liever zelfstandig wilde blijven opereren. Het heeft er overigens uiteindelijk in geresulteerd dat Liefdewerk per 1 november 1916 toch onder 'bescherming' en toezicht van het Rode Kruis kwam.

Andere beperkingen waar men tegenaan liep, waren dat pakketten naar Duitsland niet zwaarder mochten zijn dan $5 \mathrm{~kg}$. Er mochten geen krant, lucifers, brieven, uiteraard geen messen en andere wapens, maar ook geen geld in worden verpakt.

Gravin De Geloes had alleen al in Maastricht circa 250 vrijwilligers die op den duur vanuit afzonderlijke secties werkten.Behalve de vestiging in Maastricht waren er onder meer Duitse, Franse, Belgische, Britse en Russische secties van 'Liefdewerk', die werkten vanuit diverse andere steden in Nederland.

Al voor de officiële start van de Servische sectie vond verzending van pakketten aan Serviërs plaats. Het bewijs daarvan is het krantenartikel in de NRC van 31-08-1916 (zie Afbeelding 8). 
Ifet bostaur van het Internationaal lindowrork roor sewondiun en krijgsgerangemen nchrifit ons:

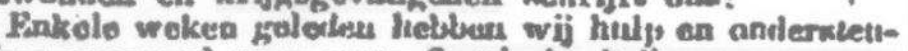
ning govrusugl roor armo Servivelio krijgsgevangonen.

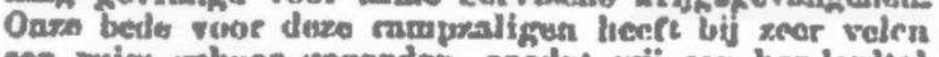

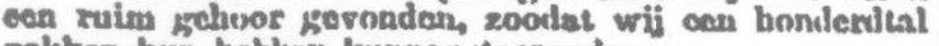
pakken hus hebber kuvnen tocennden.

Ileden ontragken wij het volgend schrijzen :

Whi dauken u oprocht poor awe bijken van lierdadigheaid, welko gai ons hubt geprever, ann ma, dn door de gehoele trervid vergotenen.

Gedarendo do nesen masaden, dat wif kriiksnovan. genen zija, hebben wrij nog van niemand eenig hlijk ran mertedoogen mogen ondervinden. Inn nw comilb hebben wij de exte liaflesuren mugen ontrangon.

Al do andero gorangenen, Itunsen, Franschen, Fingel-

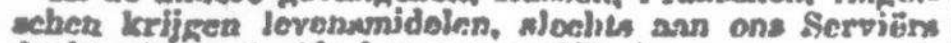
denkt niemand. Nis het $n$ mngalijk is en ons vorzack a viet al te onhencheiden voorkomt, hirlulen wij $\mathbf{u}$ sich onzor onk in do tooknmat to horinoerm.

F.t gljn hier in dil pevangenkamp 8C0 Serviêr, srantonder ean veertigtal rieken, mant buitendien berinden wich rolen ovien cn zrrakken to mididen van onk.

Sogmanis meeken wij u, zendi onk nog cenizn mwer nakken: wï zallen a er neuwiz dankhaser vons rijn.

In naam der serangonon Serviar.

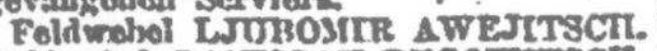
Foldwebel RANISSA REGOWTTSCII.

Vien foldwebal WOJA NASTATJHWT'TCT"

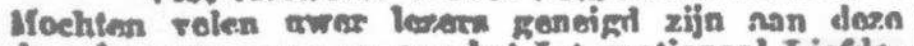
bedo fohoor to foren on an het Intermational Liefdo work roor Govionden en Krïgwgoverngenon to Maar tricht, hunge bijdmken - hoo gering mok - dnen tno komes- opdast dore rommiging den voratnotenen we lermm renigo troest en opberting in hno lijilen kmno goven, wederom eetigo varzachting mogo hrmogen in brin leed.

Afbeelding 8: Artikel NRC 31 augustus 1916

Medio 1917 werd de Servische afdeling gevormd. Secretaris werd Mej. Miroslava (Mirka) Grujic (zie Afbeelding 9).

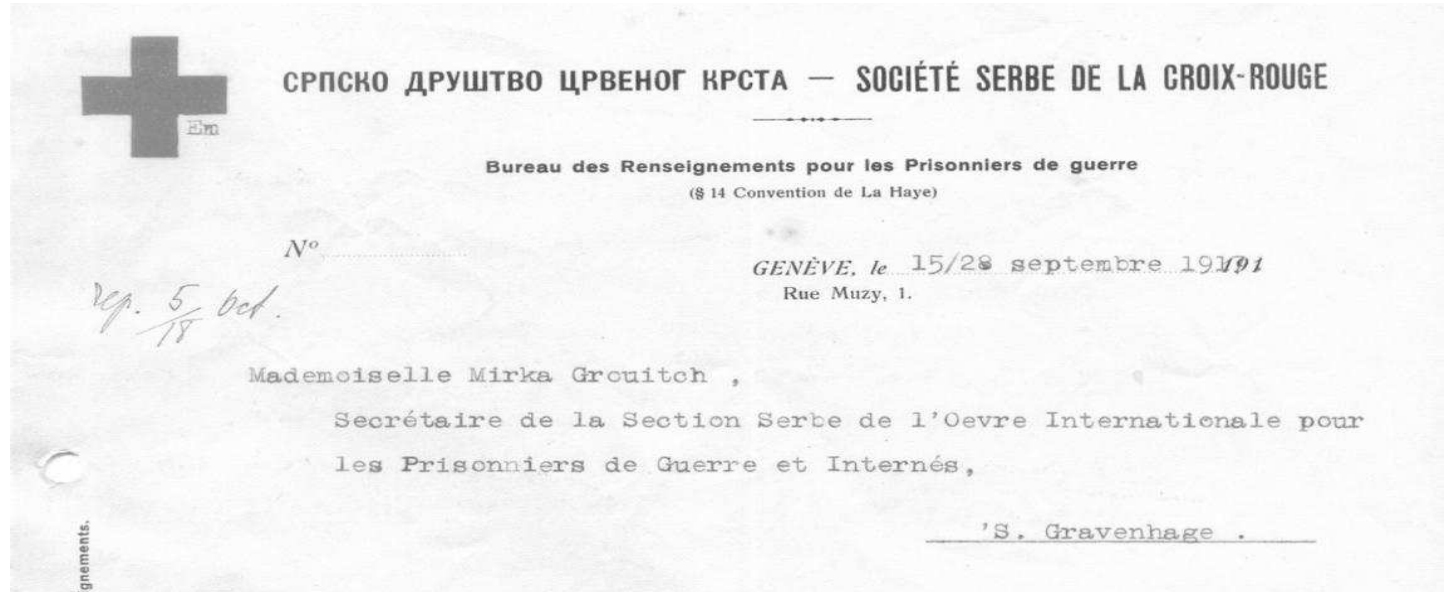

Afbeelding 9: Brief van het Servische Rode Kruis in Genève aan de secretaris van de Servische afdeling van Liefdewerk: 'Mademoiselle Mirka Grouitch, Secretaire de la Section Serbe de l'Oeuvre Internationale pour les Prisonniers de Guerre et Internées, 's-Gravenhage'. 
Volgens Wikipedia was Mirka Grujic een 'humanitair' werker. Tijdens de Balkanoorlogen was zij verpleegster en bij het begin van de Eerste Wereldoorlog was zij actief bij verschillende humanitaire acties. Vanaf 1917 zette zij zich vanuit Den Haag in voor de Servische afdeling van Liefdewerk. Haar foto is afgebeeld als Afbeelding $10 .{ }^{1}$

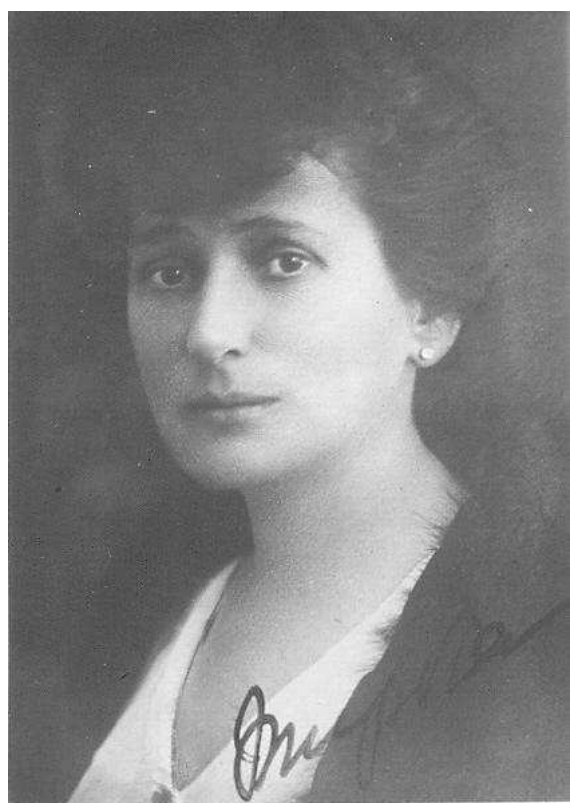

Afbeelding10: Foto van na de oorlog van de President van de'Ring van Servische Zusters' Mirka Grujic met haar handtekening.

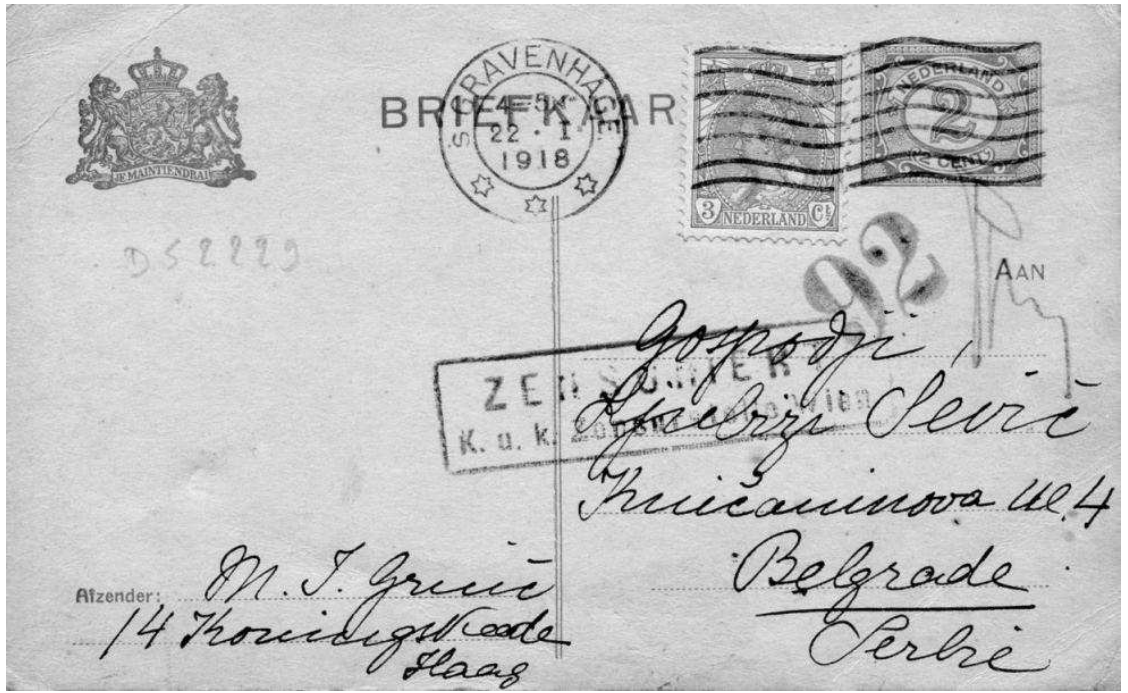

Afbeelding 11: Postwaardestuk, verstuurd door Mirka Grujic tijdens haar verblijf en werk in Nederland. Het is briefkaart van 2 cent, bijgefrankeerd met 3 cent voor buitenlands postverkeer en op 22 januari 1918 vanuit Den Haag verzonden naar Belgrado. De kaart is in Wenen gecensureerd - rechthoekige stempel - 'ZENSURIERT / K.u.K. Zensurstelle Wien'2 met de initialen van de censor in blauw. In de linker benedenhoek staat het adres van de afzender "M.J.Gruić / 14 Koningskade / Haag" (collectie Peter Poortvliet).

1 Met dank aan L. Šećerović, museum Dom Jevrema Grujic

2 K.u.K. = KaiserlicheundKönigliche 


\section{Post, door andere charitatieve organisaties gestuurd aan de Servische afdeling van Liefdewerk}

Hierna volgt een overzicht van de correspondentie van charitatieve organisaties met Liefdewerk. Het schetst een beeld van de toegewijde en gewetensvolle inzet van de Servische afdeling van Liefdewerk en illustreert de leef- en werkomstandigheden van de Serviërs in de kampen. Er is alleen post bekend die aan Liefdewerk is gestuurd, er zijn geen exemplaren gevonden van post vanuit Liefdewerk aan deze organisaties. Het gaat hier om slechts enkele stukken, maar deze zijn voldoende om het brede terrein van samenwerking met andere charitatieve organisaties te illustreren.

Charitatieve instellingen die met Liefdewerk samenwerkten waren:

- "Servische Rode Kruis" in Genève

- "Central Comité der Deutschen Vereine von Rote Kreuz"

- "Information bureau for Serbian Reliëf" in Parijs

- "Bureau de secours aux prisonniers de guerre, section Serbe" in Parijs

- "Comité de secours section Serbe" in Parchim

- "Serbian Relief Fund" in Londen

- "Comité Suisse de secours aux Serbes" in Genève

- "Oeuvre International pour blesses et prisonniers de guerre, section Russe"

- "Servische Hilfskomitee" in Frankfurt a/d Oder.

\section{Hoe Liefdewerk het leed van de Serviërs in de kampen probeerde te verzachten}

Er werden pakketten gestuurd aan krijgsgevangen en geïnterneerde Serviërs in kampen in Oostenrijk, Hongarije en Duitsland. Hoe Liefdewerk aan hun adressen kwam is niet bekend. Aangenomen mag worden dat Liefdewerk de informatie ontving van het Internationale of van het Servische Rode Kruis. Zeker is dat er ook Serviërs zelf vanuit de kampen naar Liefdewerk hebben geschreven. Dit kan worden gestaafd door de kaart afgebeeld in Afbeelding12/13. 


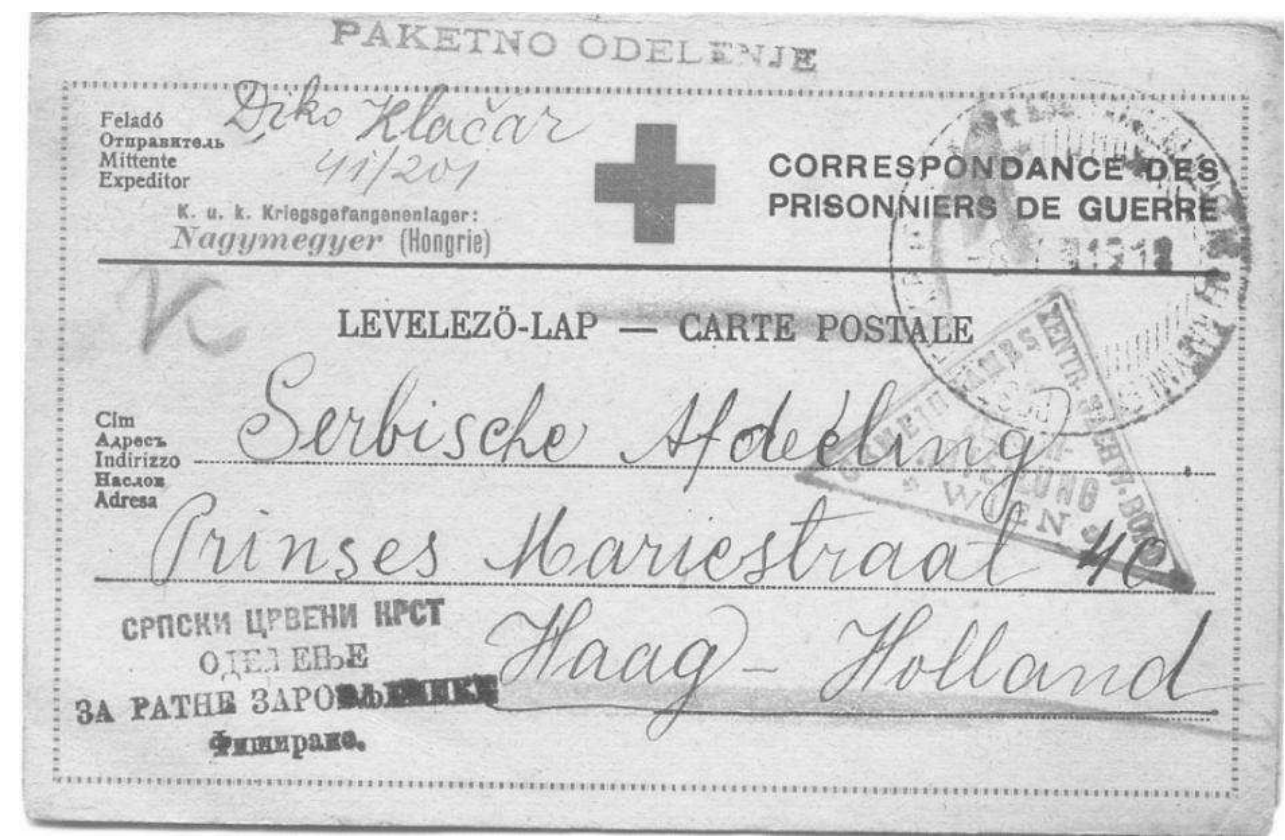

Afbeelding 12: De Rode Kruis kaart voor 'Correspondance des Prisonniers de Guerre' werd verstuurd vanuit het kamp Nagymegyer (kampstempel) op 5 mei 1918 via Wenen (driehoekige censuurstempel 'Gemeinsames Zentr.Nachw.Büro/Zensurabteilung Wien' met de initialen van de censor in blauw), in Genève gestempeld door het Servische Rode Kruis / afdeling / POW / fiširano (in cyrillisch) en verstuurd naar de Servische afdeling van Liefdewerk in Den Haag.

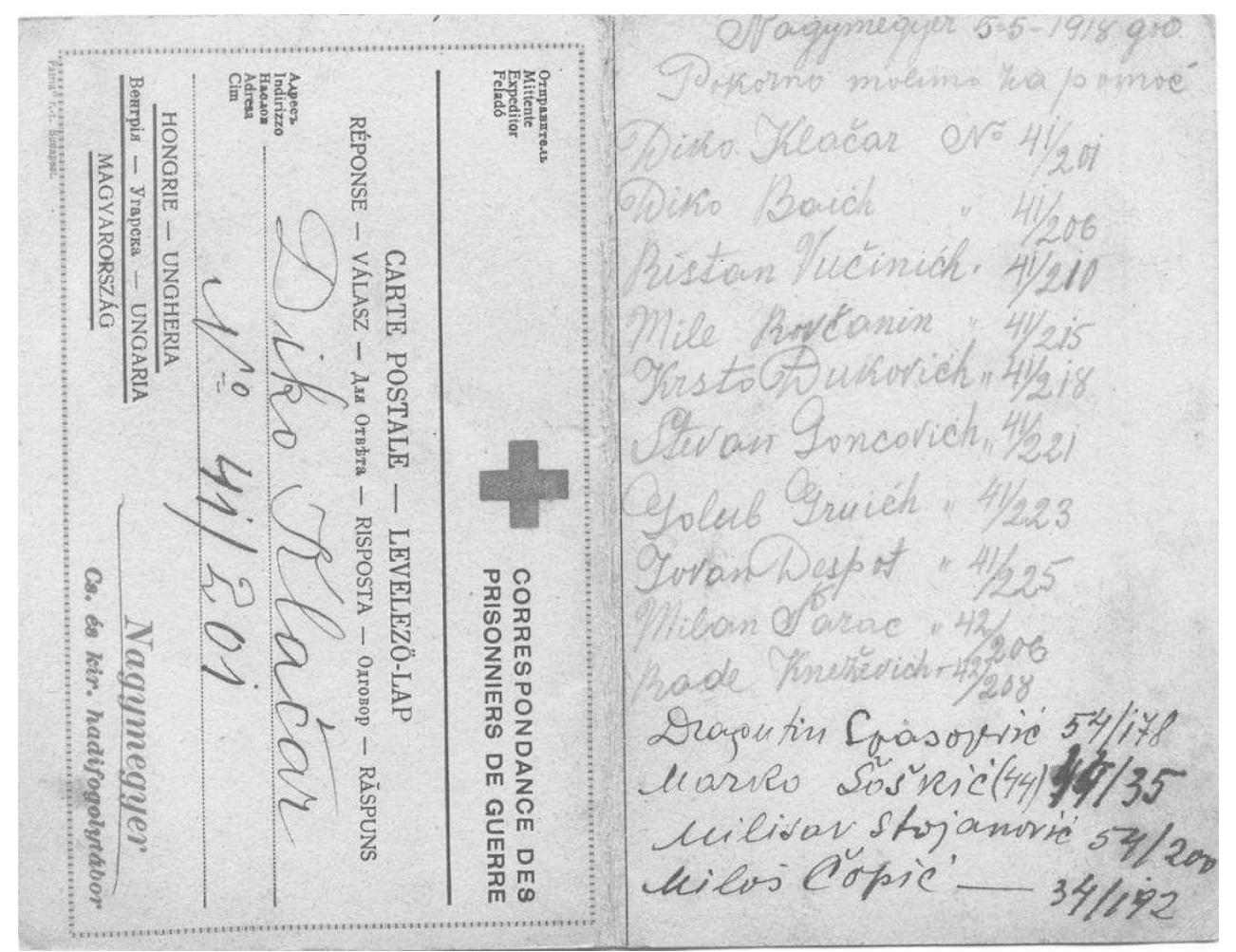

Afbeelding 13: Op de keerzijde (zie Afbeelding12) van deze tweedelige ansichtkaartvan het Rode Kruis (deel voor het antwoord) was het verzoek om hulp van Liefdewerk, niet slechts door één gevangene ondertekend, maar door niet minder dan 14 gevangen Serviërs. 


\section{Pakketkaarten en krijgsgevangenkaarten}

Er waren twee soorten kaarten in gebruik: een waarbij de afzender de ontvanger op de hoogte stelde dat er een pakket onderweg was (pakketkaart) en de tweede, die bijgevoegd was in het pakket, waarop de ontvanger bevestigde dat het pakket was aangekomen (antwoordkaart). De kaarten werden bedrukt in de verschillende talen van de ontvangers. Voorwaarde aan de ontvangers was dat zij, om wederom een pakket te ontvangen, de retourkaart ingevuld moesten terugsturen.

Voorbeelden van pakketkaarten (de data van invoering zijn niet bekend)

Uit onderzoek van ruim 80 kaarten blijkt dat twee types van pakketkaarten werden gebruikt:

Eén met opdruk "Internationaal Liefdewerk........... onder bescherming van ' $t$ Nederlandsche Roode Kruis"

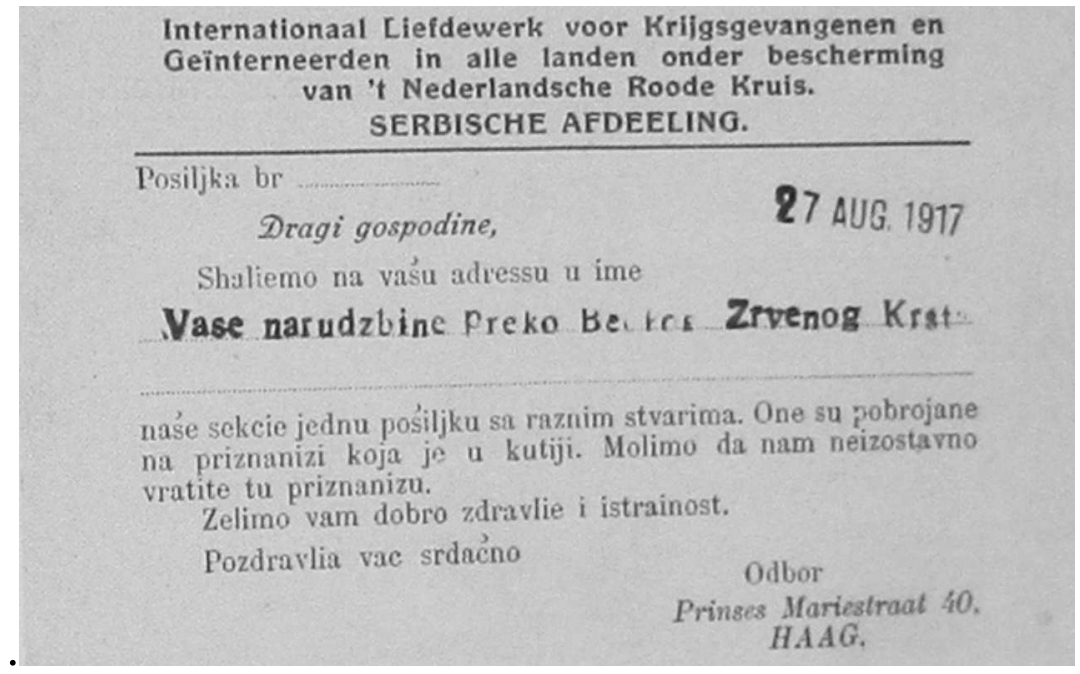

Afbeelding 14: Keerzijde van de 'pakketkaart' van Liefdewerk voor Serviërs.

De overige tekst op de keerzijde van Afbeelding14 is in het Servisch. Vertaald luidt de tekst als volgt:

"Zending no.......

Geachte heer,

Wij zenden u namens .....(naam sponsor)

Onze afdeling stuurt $\mathrm{u}$ een zending met diverse artikelen, die vermeld staan op het in de doos ingesloten ontvangstbewijs (NB. de zgn. "Krijgsgevangenkaart" of "antwoordkaart"). Stuurt u deze onverwijld retour.

Wij wensen u een goede gezondheid en doorzettingsvermogen.

Met vriendelijke groet,

Afdeling

Prinses Mariestraat 40

Haag 


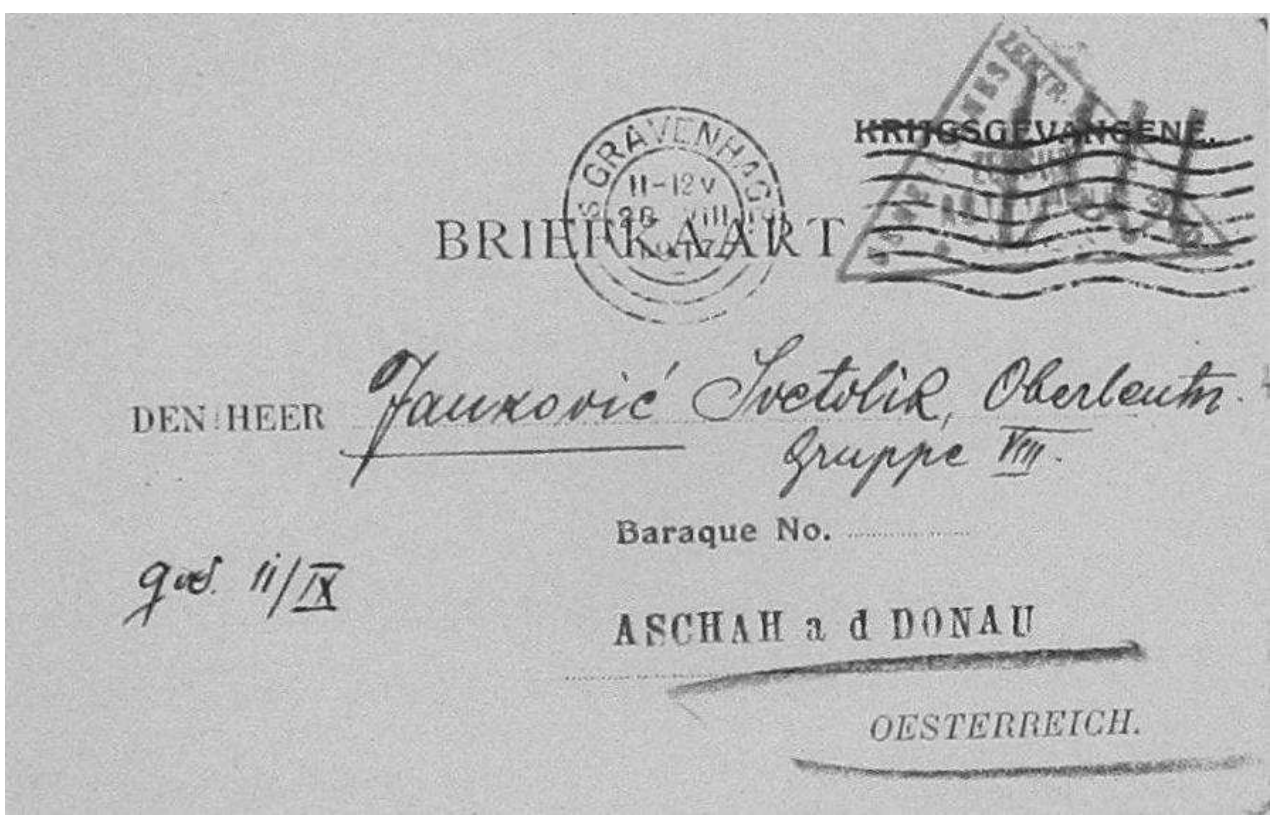

Afbeelding 15: Adreszijde pakketkaart

Op de adreszijde van dit type kaart (zie Afbeelding 15) is basisinformatie voorgedrukt, zoals: 'KRIJGSGEVANGENE', 'BRIEFKAART', 'DEN HEER', 'Baraque No. .........' en 'OESTERREICH'. Tussen de tekst 'Baraque No.' en 'OESTERREICH' werd ruimte gelaten waar de plaats van bestemming kon worden ingevuld - in dit geval met een rubberstempel van de stad waar het kamp was - 'Aschah a.d. Donau'3.

Op het tweede type kaart is op de voorkant de indeling iets gewijzigd. Onder de tekst 'Baraque' staat nog 'Gruppe' en behalve 'Oesterreich' is toegevoegd 'Ungarn'. Het administratief stempel van Liefdewerk is linksboven gezet (zie Afbeelding16).

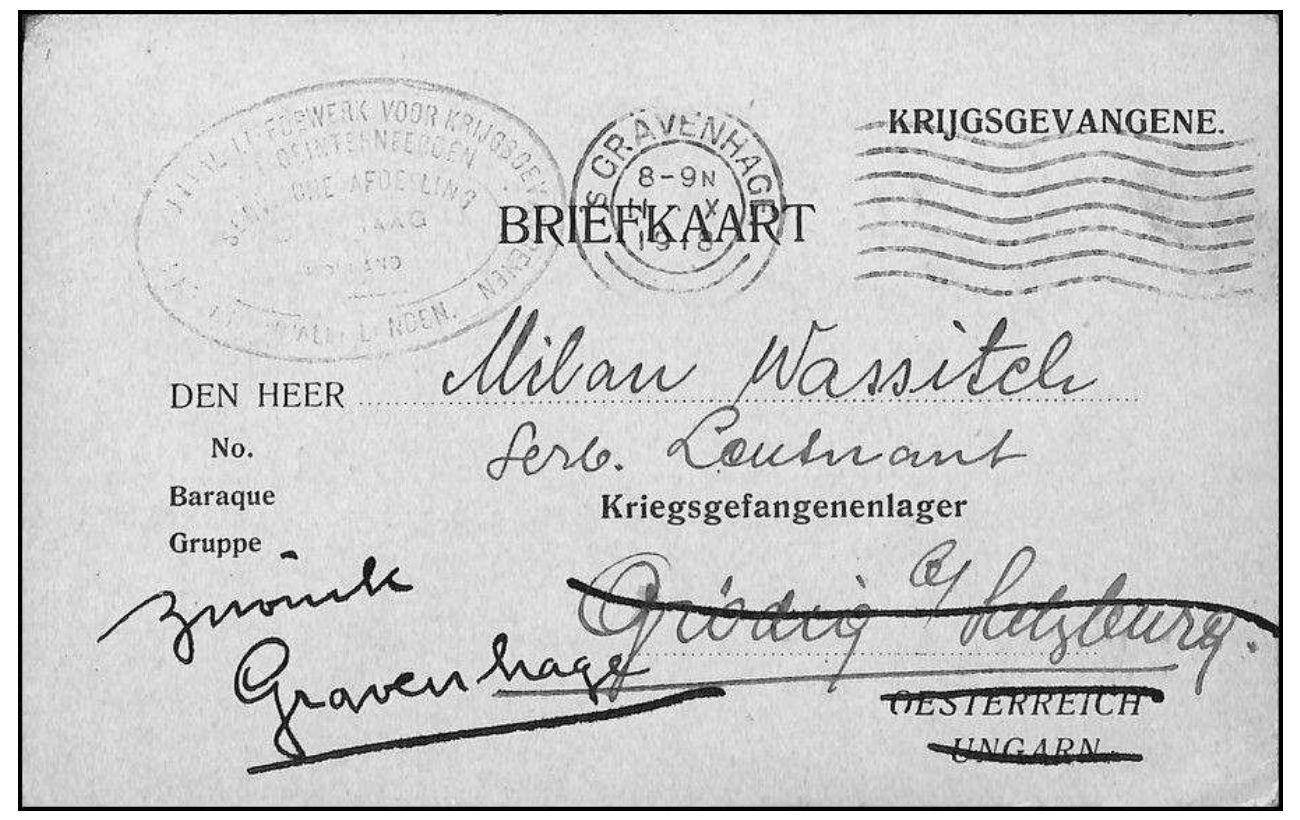

Afbeelding 16: Adreszijde van het tweede type pakketkaart. De kaart is naar het Servische krijgsgevangenenkamp in Grōdig bei Salzburg gestuurd en teruggestuurd naar Den Haag. Het stempel van Liefdewerk is linksboven afgedrukt.

3 Correcte schrijfwijze $=$ Aschach 


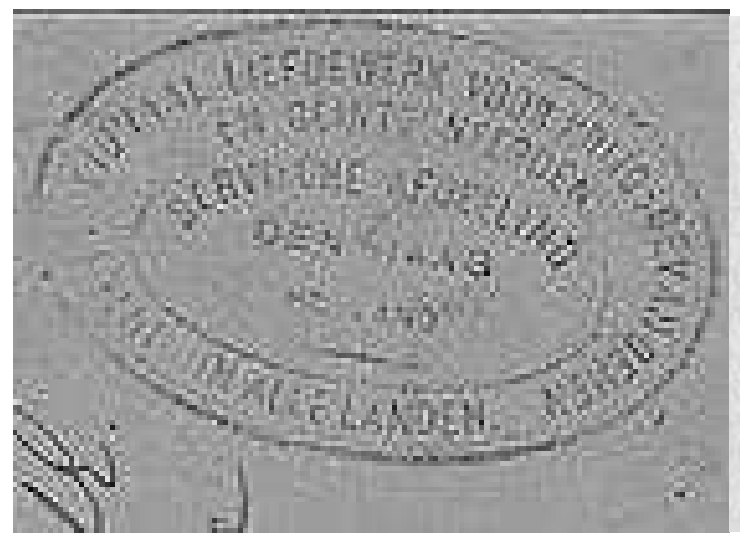

BRI

Afbeelding 17: Het Administratieve Stempel van Liefdewerk: 'INTERNATIONAAL LIEFDEWERK VOOR KRIJGSGEVANGENEN en GEINTERNEERDEN IN ALLE LANDEN / SERVISCHE AFDEELING / DEN HAAG / HOLLAND' (paars en grijs)

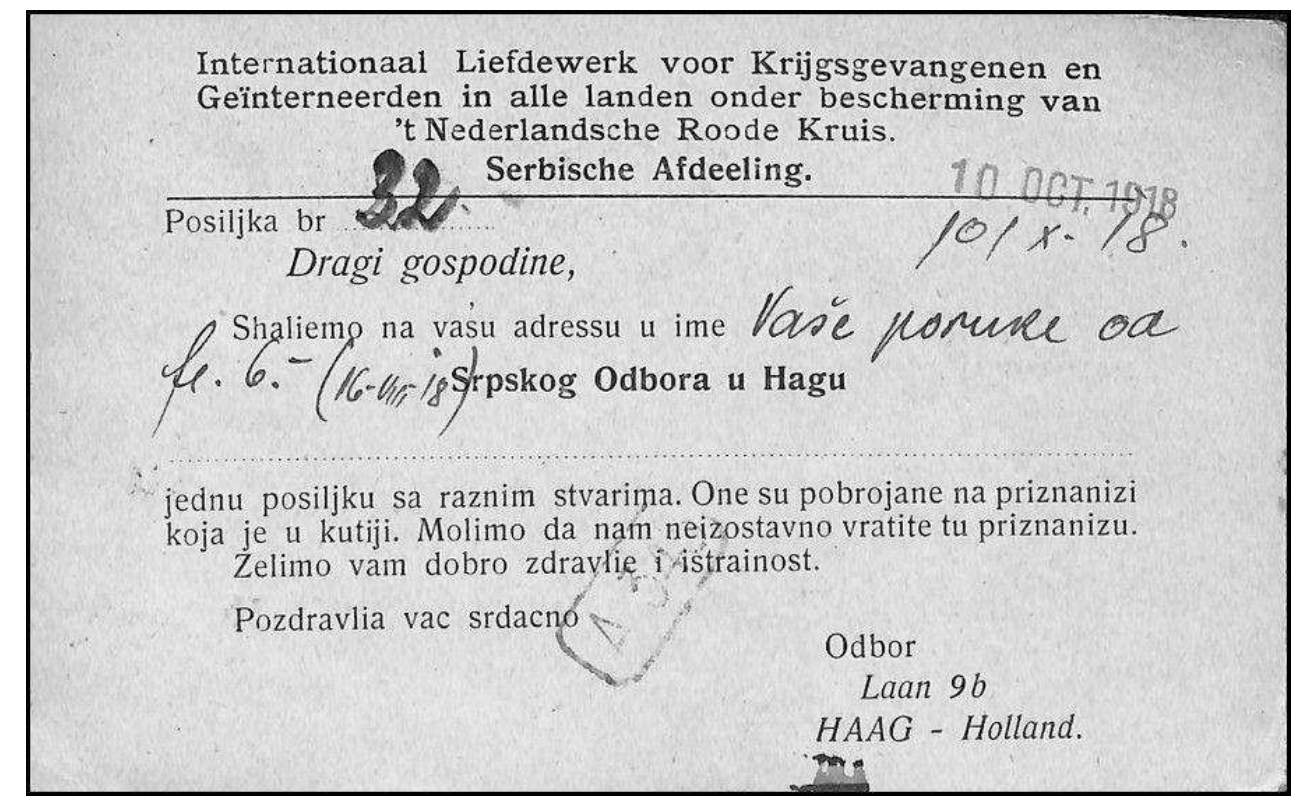

Afbeelding.18. Keerzijde van Afbeelding16.

Dekeerzijdevan dekaart (zie Afbeelding 18)laat, in aanvullingophetLiefdewerkstempel, zien dat het voor Servische gevangenen en geïnterneerden bestemd is. De Servische tekst is vrijwel hetzelfde als van het eerste type, zelfs met dezelfde fouten. Het verschil is het adres van Liefdewerk, nu Laan 9b Haag, waaraan nu ook Holland is toegevoegd. "Srpski odbor" betekent "Servische afdeling".

Op beide kaarten wordt benadrukt dat de ontvangst van het pakket en de inhoud door de ontvanger moet worden bevestigd.

\section{Antwoordkaart door de krijgsgevangenen te versturen (Kriegsgefangenen-Karte)}

Zoals eerder opgemerkt werkte Liefdewerk eerst volledig zelfstandig, maar moest zij vanaf eind 1916 werken ondertoezicht van het Nederlandse Rode Kruis. Hierna volgen voorbeelden van kaarten uit beide periodes. 


\section{Liefdewerk zelfstandig}

De enige ongebruikte antwoordkaart (te versturen door de krijgsgevangene) uit de eerste periode die de auteur bekend is, wordt hier uitvoerig beschreven (zie Afbeelding 19). De kaart is tweetalig omdat de Servische gevangenen in Duitse en Oostenrijks-Hongaarse kampen gevangen werden gehouden. Op de voorkant is naast de adressering aan de bovenkant in het Servisch de regel te lezen: 'bevestiging van zending nr.......' en 'gezonden'...

De Duitse naam van de kaarten was 'KRIEGSGEFANGENEN-KARTE' met als geadresseerde de naam van Liefdewerk in het Duits 'INTERNATIONALES LIEBESWERK / Für Kriegsgefangene / (Serbische Abteilung)', en het adres van Liefdewerk 'MAASTRICHT S.S. (HOLLAND).'

Op de linkerzijde staat de volgende tekst in het Servisch (Kroatisch):

toegestuurd.'

'Krijgsgevangene die deze kaart niet terugstuurt krijgt niet nog een pakket Hieronder is een ruimte voor opmerkingen ('biljezke').

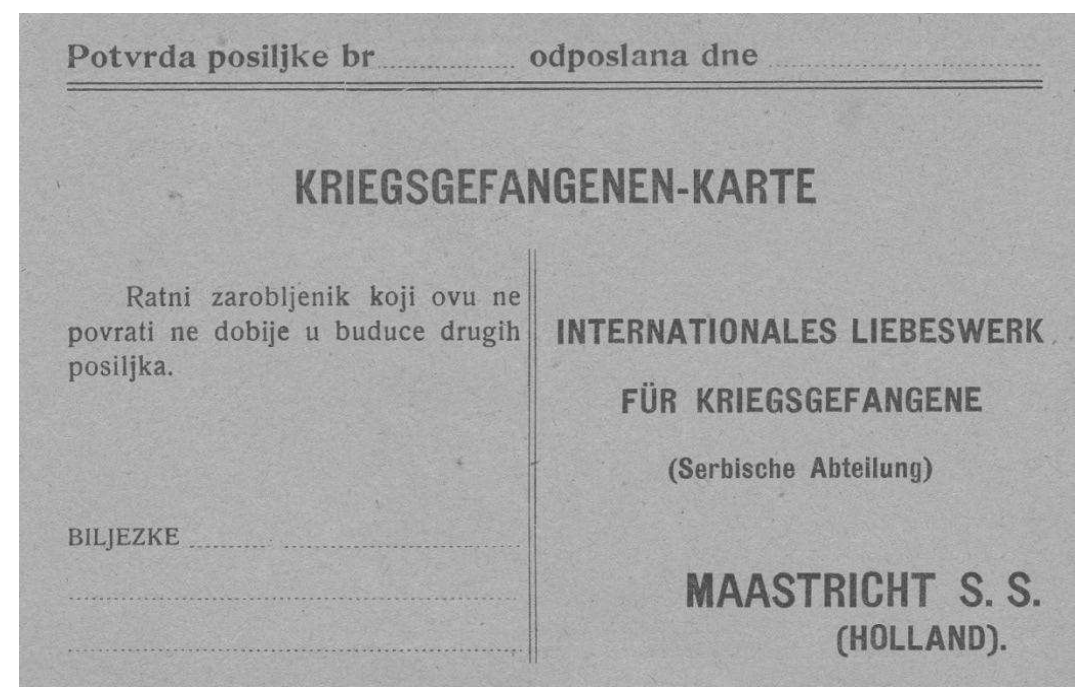

Afbeelding 19: Antwoordkaart (Kriegsgefangenen-karte)

De keerzijde van deze kaart (Afbeelding19) wordt in Afbeelding 20 weergegeven met de volgende tekst:

Ik, ondergetekende .....

Geboren in.......

Voor de oorlog wonende .......

Regiment, compagnie, bataljon.........

Door de handel.....

Krijgsgevangen in.....

Bevestigt ontvangst in goede orde van......

Aan de zijde van de

Een pakket bevattende....., afgesloten met,

Duidelijke signatuur 
Loodrecht op de tekst staat in het Servisch en aan de andere zijde in het Duits het volgende: Da diese Karte nicht zur Familie bestimmt ist darf sie ausser der den Kriegsgefangene erlaubten Korrespondent geschickt werden.

Er is helaas nog geen gebruikt voorbeeld van deze kaart gevonden, dus of deze daadwerkelijk in omloop is geweest, kan niet worden aangetoond.

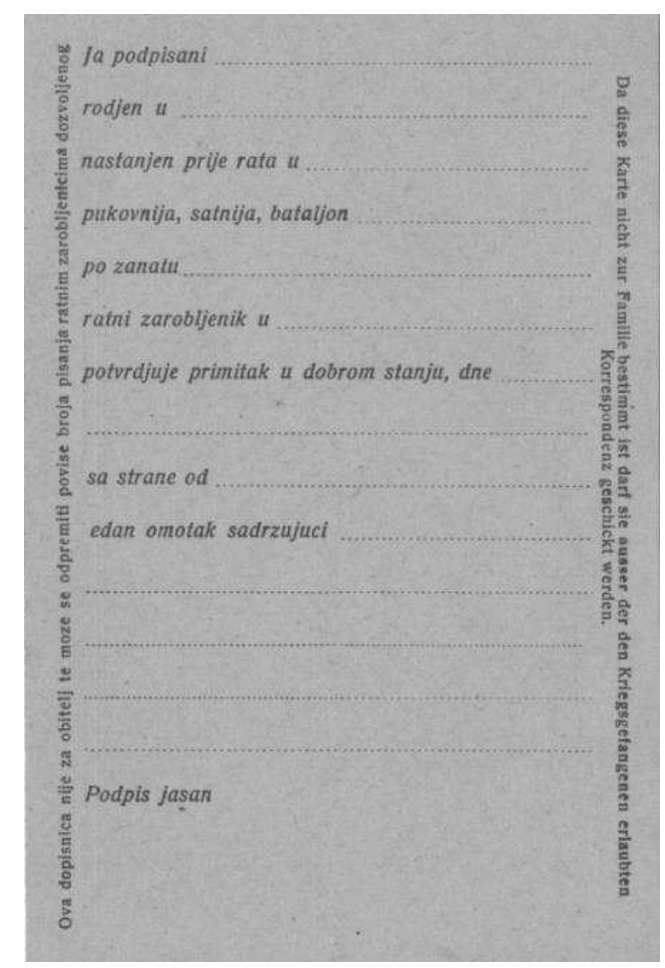

Afbeelding 20: Keerzijde van Afbeelding19

\section{Liefdewerk onder toezicht van het Nederlandse Rode Kruis}

Van de in deze periode gebruikte antwoordkaarten is een beperkt aantal bekend, waarbij drie basistypen kunnen worden onderscheiden. Het onderscheid wordt gemaakt op basis van het adres op de voorzijde:

Type I - Prinses Mariestraat 40, 's Gravenhage

Type II - Prinses Mariestraat 40, Den Haag Nederland

Type III - Laan 9b Den Haag Nederland.

\section{Type I}

Type I zal uitgebreid worden besproken om de verschillen met de ander types te verduidelijken.

Na bestudering van 19 kaarten bleek, dat deze kaarten in de periode van 26 april 1917 (mogelijk eerder) tot eind 1917 (datum laatste bekende kaart) in gebruik waren. 
De adreszijde (zie Afbeelding 21) toont links basisinformatie over de afzender:

naam van de afzender......

krijgsgevangen in.

datum van ontvangst van de zending.......

En rechts de Nederlandse adressering aan:

Internationaal Liefdewerk voor krijgsgevangenen en geïnterneerden in alle landen onder bescherming van het Nederlandsche Roode Kruis

(Serbische Afdeeling).

Prinses Mariestraat 40

's-Gravenhage

Holland (in potlood toegevoegd)

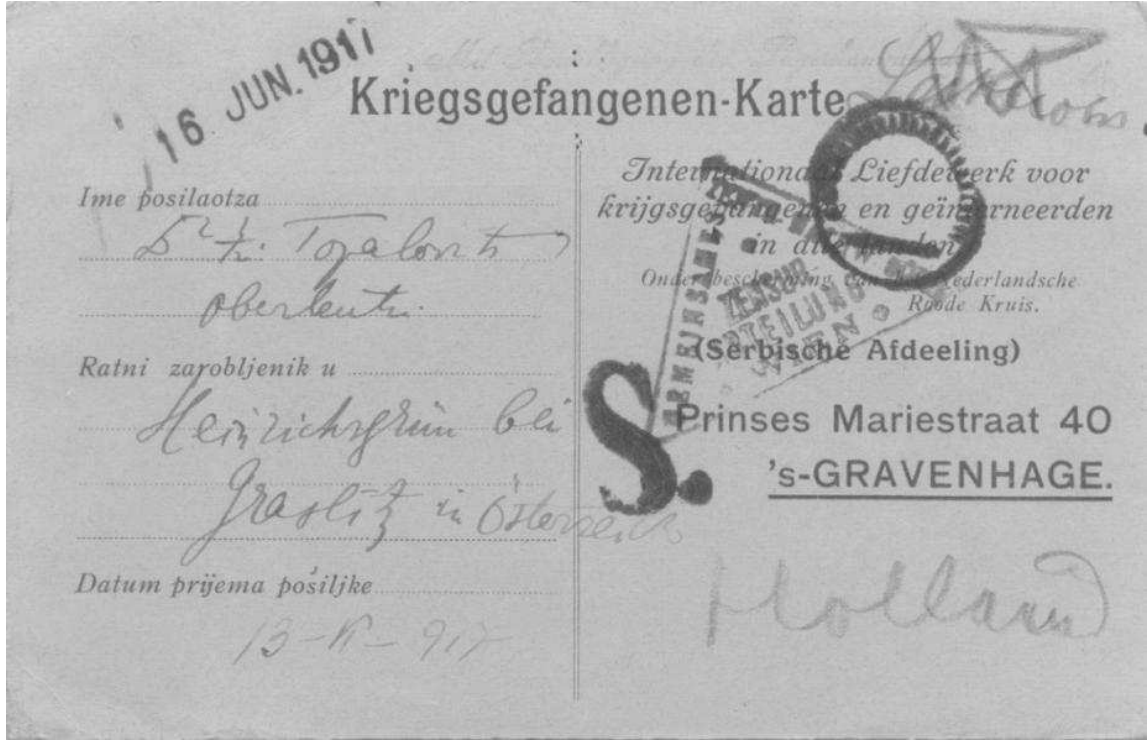

Afbeelding 21: Antwoordkaart Type I.

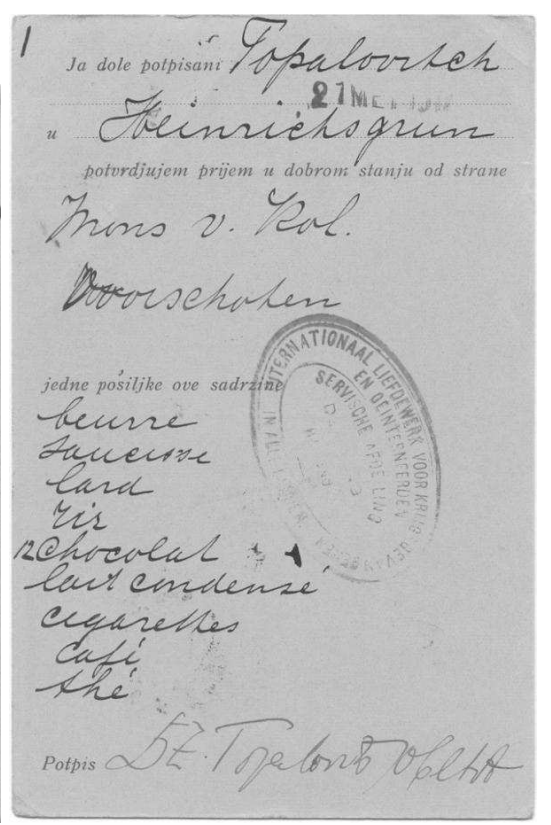

Afbeelding 22: Keerzijde van Afbeelding 21.

De kaart van Afbeeldingen 21/22 is op 16 juni 1917 gestuurd uit kamp 'Heinrichsgrün' Oostenrijk via de Gemeinsames zentr(al) Nachw(eis) Bureau/Zensurabteilung/ Wien (initialen censor in blauw), (=GZNB/Wien). De zending werd op 13 Mei 1917 ontvangen. Het dikke stempel S wil zeggen dat het een Servische gevangene betreft. Het ronde stempel is het kampstempel.

Op de adreszijde van de kaart (zie Afbeelding 21) is de gedrukte tekst als volgt:

De adreszijde toont links basisinformatie over de afzender: naam van de afzender......

krijgsgevangen in. datum van ontvangst van de zending......" 
De stempels op de achterzijde (zie Afbeelding 22) zijn van Liefdewerk en de datum waarop de zending werd verzonden (21 mei 1917). In handschrift is ingevuld wat is verzonden (de inhoud van het pakket) en van welke sponsor het pakket afkomstig is, en aan de ontvanger is verstuurd, de laatste heeft de kaart ondertekend.

Uit bovenstaande gegevens kan het volgende worden afgeleid:

- de tijdsduur van de zending aan de hand van de data waarop het pakket verstuurd is en het tijdstip van ontvangst;

- de inhoud van de zending;

- of de inhoud van de zendingen overeenkwam met de opgave;

- de gemiddelde kosten van een pakket kon worden bepaald door de waarde in guldens te delen door het aantal verzonden pakketten (zie tabel 1). (Lith 2011:122)

Van enkele kaarten Type 1 blijken meerdere soorten te bestaan. De voorzijde van de eerste drie zijn identiek bedrukt, het gaat hier om de achterzijdes.

We nemen een antwoordkaart, net als het eerder genoemde voorbeeld verstuurd vanuit een kamp in Aschach (kampstempel) op 26 september 1917 via het 'GZNB/Wien'. Op het eerste gezicht is niets afwijkends te zien. Zoals de volgende afbeelding toont, wordt de kaart, bedrukt met de volledige plaatsnaam en de naam van de sponsor, uit Nederland verstuurd naar Aschach a. Donau en 'bevestigt ontvangst in goede staat door...., geschonken door de Kriegsgefangenenhilfe Christlicher Verein Junger Männer'. Deze wijziging wordt als Type IA aangemerkt (afb. 23 Type IA). Op de achterkant van de tweede kaart is de plaatsnaam gedrukt: Grodig bei Salzburg (zie Afbeelding 23 Type IB). De volgende kaart (zie Afbeelding 23 Type IC) is aan de achterkant afwijkend, het woord 'patiënt' is daar toegevoegd, zodat de tekst op de achterzijde luidt:

'Patiënt in Frankfurt a. Oder....... bevestigt ontvangst in goede staat (van pakket gesponsord) door....... "SerbianRelief Fund' te London.'

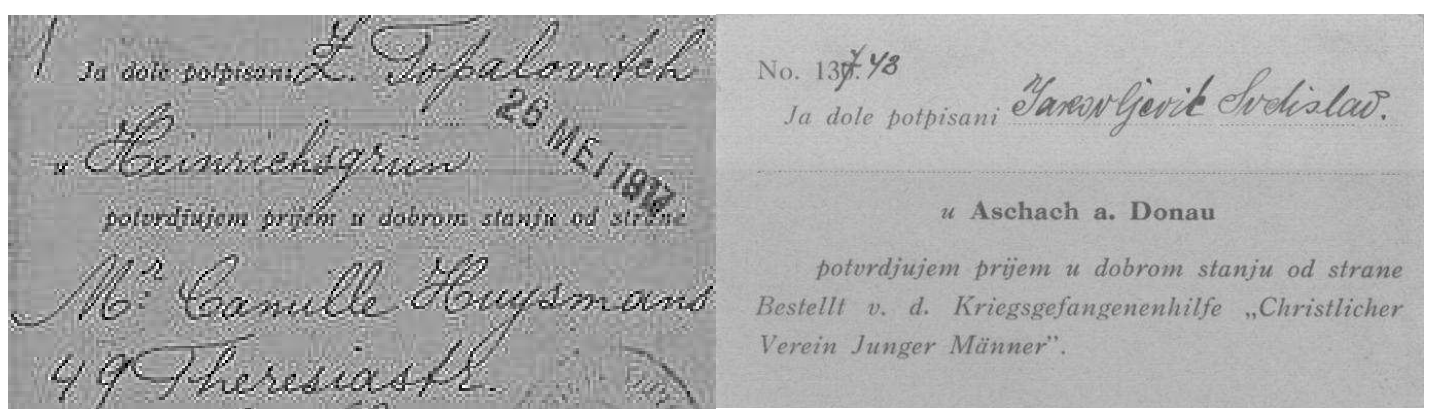

Type I

Type IA 


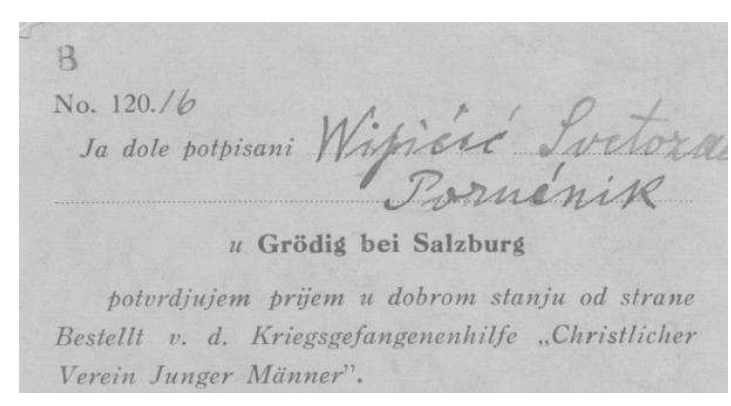

Type IB

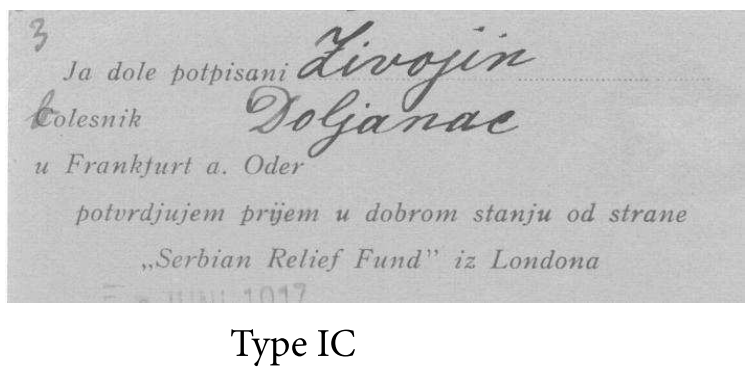

Type IC

Afbeelding 23: Types I, IA, IB en IC.

\section{Type II}

Bij de kaart Type II is het verschil met Type I alleen het adres: Prinses Mariestraat 40 Den Haag (Nederland). Na bestudering van de beschikbare kaarten kan worden gesteld dat deze in de periode tussen 22 december 1917 of eerder en zeker t/m 24 april 1918 in gebruik waren.

Niet afgebeeld is de voorzijde van de kaart Type II (zie Afbeelding 24), op 19 maart 1918 naar Den Haag verstuurd vanuit het kamp Nezsider in Hongarije met het gebruikelijke stempel 'GZNB/Wien'. De achterkant toont, naast andere data, het stempel 'Servische afdeling' (SRPSKI ODBOR).

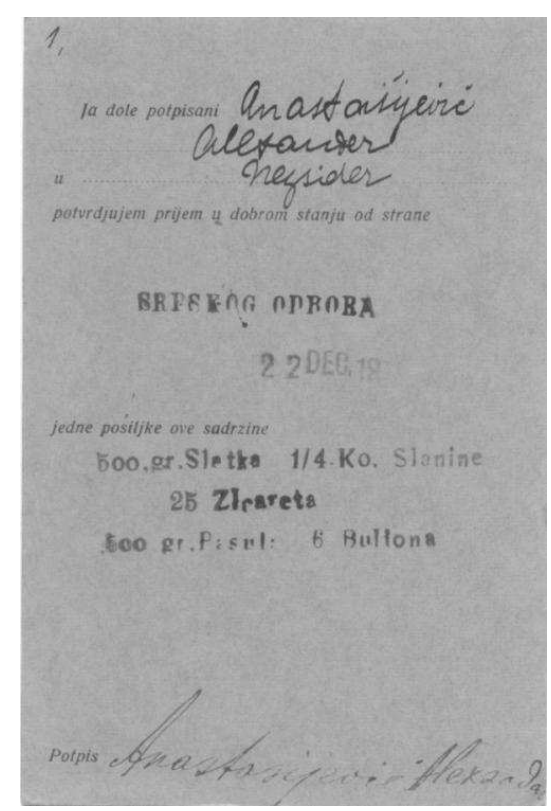

Afbeelding 24: keerzijde kaart Type II.

Het is waarschijnlijk dat op latere uitgaves van Type II kaarten meer gedrukte invulvakken zijn geweest zoals bij de kaarten Type I, maar tot dusver zijn deze niet opgedoken. 


\section{Type III}

Het adres Laan 9b Den Haag (Holland) werd gebruikt tussen 28 juli 1917 (of eerder) en zeker $\mathrm{t} / \mathrm{m} 27$ augustus 1918. Dit kan worden geconcludeerd na bestudering van 12 kaarten van dit type.

Een kaart (zie Afbeelding 25) verstuurd vanuit het kamp Braunau op 8 juni 1918 (kampstempel in grijs), via Wenen naar Den Haag met het stempel 'GZNB/ Zensurabteilung/Wien'. Datum ontvangst is 5 juni 1918. De voorkant is niet afgebeeld.

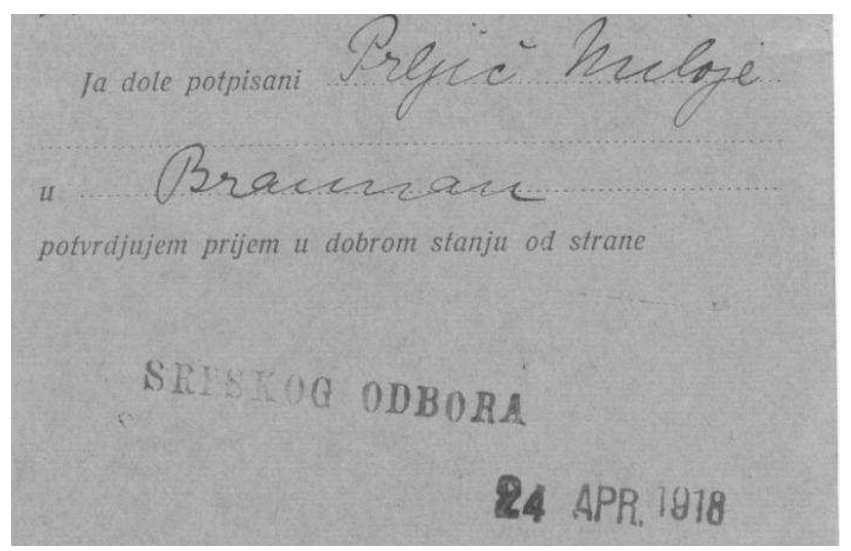

Afbeelding 25: Detail van achterzijde kaart Type III.

De volgende kaart is vanuit kamp Braunau verstuurd met, behalve het gebruikelijke stempel van het bureau in Wenen met de censor-initialen in blauw, ook het kampstempel 'K.u.K.: Gefangenenlager/5 juli 1918/Braunau I./B.. Het verschil zit in de achterkant (zie Afbeelding 26) waar gedrukt staat: 'bevestigt ontvangst in goede staat door.... "Servische afdeling in Den Haag"' (Srpskog Odbora u Hagu). Dit wijkt af van de andere Type III kaart, wordt dus Type IIIA.

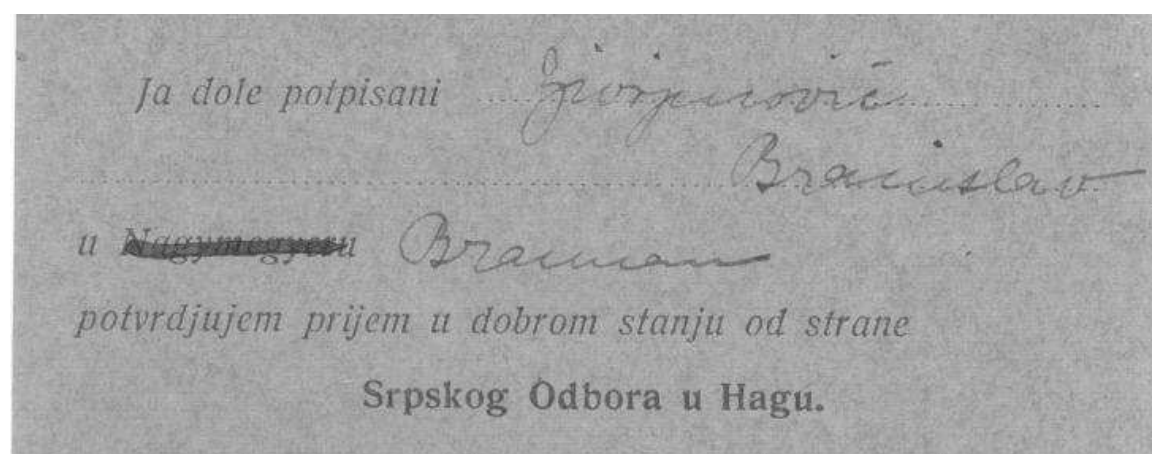

Afbeelding 26: Detail van achterzijde kaart Type IIIA.

Op basis van de getoonde kaarten kan worden geconcludeerd dat er minstens acht verschillende types antwoordkaarten voor Servische gevangenen zijn gebruikt om de ontvangst van een pakket te bevestigen. Eén in de periode dat Liefdewerk zelfstandig opereerde en zeven in de tijd dat Liefdewerk viel onder toezicht van het Rode Kruis. Het is echter waarschijnlijk dat er nog meer soorten kaarten in omloop waren. 


\section{Overzicht van verzonden pakketten}

In de volgende tabel, overgenomen uit het boek van Hans van Lith, staan de aantallen verzonden pakketten en de daarmee gemoeide bedragen. Het geeft een goed beeld van de indrukwekkende hoeveelheid door Liefdewerk verstuurde pakketten.

\begin{tabular}{|l|l|l|l|l|l|l|}
\hline Krijgsgevangen & $\mathbf{1 9 1 6}$ & \multicolumn{1}{l}{$\mathbf{1 9 1 7}$} & $\mathbf{1 9 1 8}$ & \\
\hline $\begin{array}{l}\text { (bedragen in } \\
\text { duizend guldens) }\end{array}$ & $\begin{array}{l}\text { Aantal } \\
\text { pakketten }\end{array}$ & bedrag & $\begin{array}{l}\text { Aantal } \\
\text { pakketten }\end{array}$ & bedrag & $\begin{array}{l}\text { Aantal } \\
\text { pakketten }\end{array}$ & bedrag \\
\hline Belgen & 161.452 & $\mathbf{2 8 1 , 9}$ & 356.383 & 783,0 & 200.903 & 480,7 \\
\hline Fransen & 32.047 & 64,1 & 37.612 & 68,8 & 75.157 & 153,0 \\
\hline $\begin{array}{l}\text { Duitsers } \\
\text { Oostenrijkers } \\
\text { Hongaren }\end{array}$ & 769 & 1,9 & 3.741 & 12,2 & 2.410 & 5,6 \\
\hline Britten & 21.578 & 32,4 & 21.280 & 39,5 & 6.040 & 16,8 \\
\hline Russen & 288.768 & 577,5 & 962.119 & 2307,6 & 211.163 & 888,8 \\
\hline Italianen & 2.544 & 5,5 & 3.800 & 7,47 & 3.217 & 9,8 \\
\hline Roemenen & 143 & 607,8 & 3.731 & 11,234 & 3.509 & 10,3 \\
\hline Serviërs & $\mathbf{2 0 . 3 2 1}$ & $\mathbf{8 1 , 3}$ & $\mathbf{1 2 . 3 5 3}$ & $\mathbf{6 1 , 9}$ & $\mathbf{1 4 . 3 9 5}$ & $\mathbf{7 5 , 5}$ \\
\hline Grieken & & & 15 & 0,062 & 146 & 0,7 \\
\hline Polen & & & 3.201 & 11,9 & 10.355 & 46,0 \\
\hline totaal & 527.622 & $1.045,2$ & 1.404 .235 & 3.302 .6 & 527.295 & 1.687 .1 \\
\hline
\end{tabular}

Tabel 14: Overzicht van verzonden pakketten per jaar en de kosten (x 1.000 gulden).

Aan Serviërs in de kampen werd van $1916 \mathrm{t} / \mathrm{m}$ 1918, een totaal van 47.069 pakketten verstuurd voor een bedrag van 218.700 gulden. Het totale aantal pakketten dat Liefdewerk in de Eerste Wereldoorlog vanuit Nederland verzond, bedroeg 2.539.265. De waarde van deze zendingen uitgedrukt in guldens was 6.225.779.

\section{De kostprijs van een pakket}

Uit de gegevens van tabel 1 kan men de kostprijs van een pakket berekenen. Het resultaat hiervan is te zien in tabel 2 :

\footnotetext{
4 De eerste verzending naar de Serviërs vond in 1916 plaats, de tabel van 1915 is daarom niet overgenomen. In de bedragen is niet de waarde (deze is onbekend) van de 317.234 pakketten die door particulieren aan Liefdewerk zijn aangeboden ter doorzending. Hans van Lith blz.122/123.
} 


\begin{tabular}{|l|l|l|l|l|}
\hline Krijgsgevangenen & $\mathbf{1 9 1 5}$ & $\mathbf{1 9 1 6}$ & $\mathbf{1 9 1 7}$ & $\mathbf{1 9 1 8}$ \\
\hline Belgen & $\mathbf{2 , 2 7}$ & $\mathbf{1 , 7 5}$ & $\mathbf{2 , 2 0}$ & $\mathbf{2 , 4 0}$ \\
\hline Fransen & $\mathbf{2 , 5 0}$ & $\mathbf{2 , 0 0}$ & 1,88 & $\mathbf{2 , 0 4}$ \\
\hline Duitsers & $\mathbf{2 , 2 6}$ & $\mathbf{2 , 4 9}$ & 3,27 & 2,31 \\
\hline Britten & $\mathbf{2 , 0 6}$ & 1,50 & 1,85 & $\mathbf{2 , 7 7}$ \\
\hline Russen & 1,85 & $\mathbf{2 , 0 0}$ & $\mathbf{2 , 4 0}$ & $\mathbf{2 , 7 7}$ \\
\hline Italianen & & $\mathbf{2 , 1 5}$ & 1.97 & 3,05 \\
\hline Roemenen & & $\mathbf{4 , 2 4}$ & 3,01 & $\mathbf{2 , 9 2}$ \\
\hline Serviërs & & $\mathbf{4 , 0 0}$ & $\mathbf{5 , 0 1}$ & $\mathbf{5 , 2 5}$ \\
\hline Grieken & & & $\mathbf{4 , 1 3}$ & 5,02 \\
\hline Polen & & & 3,72 & $\mathbf{4 , 4 4}$ \\
\hline
\end{tabular}

Tabel 2: Gemiddelde prijs van een pakket.

Uit de berekening van de prijs blijkt heel verrassend, dat de pakketten voor Serviërs verreweg het duurste waren. Een reden hiervoor is niet gevonden. Op twee kaarten verzonden uit kamp Aschach (zie Afbeelding 27) stonden op de achterkant wel gegevens waarmee de berekende prijzen werden bevestigd. De resultaten zijn opmerkelijk consistent, bewijzen de opsommingen van genoemde kaarten. Het totaalbedrag is steeds rond de 5 gulden.

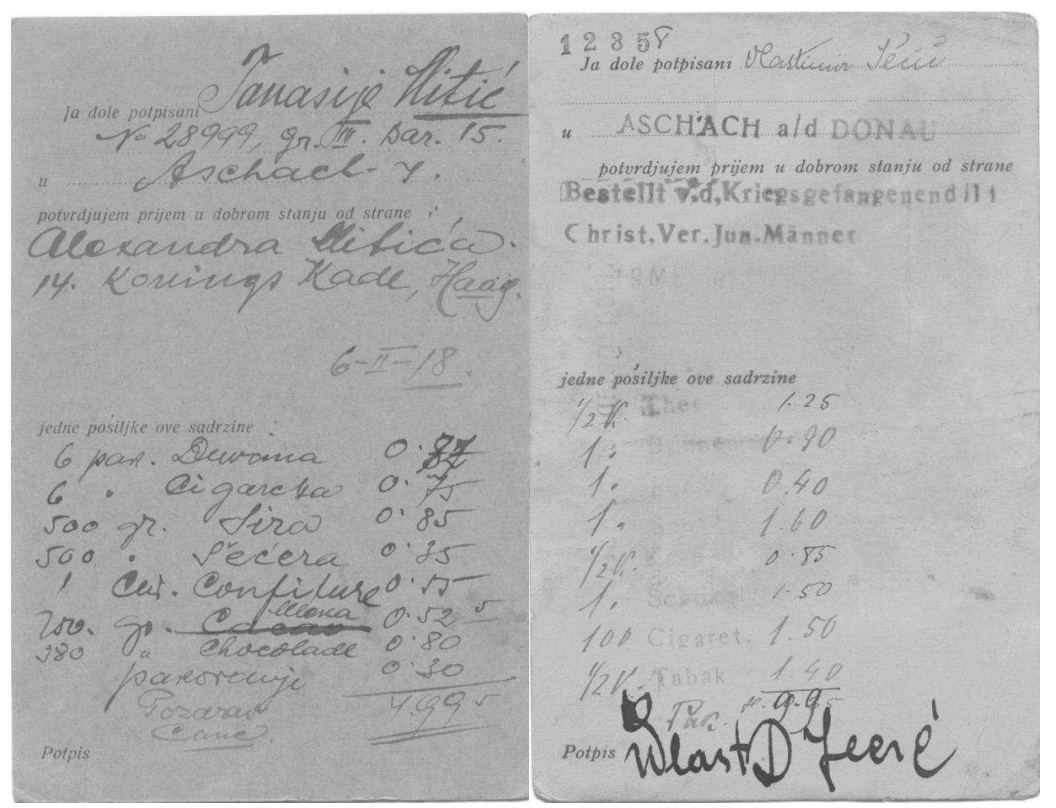

Afbeeldingen 27 en 28: De keerzijdes van twee naar het kamp Aschach verstuurde kaarten met een waardeopgave van de meegezonden artikelen. 


\section{Inhoud van de zendingen}

Bestudering van de kaarten van 15 kampen leidt tot de conclusie dat de inhoud van de zendingen vooral bestond uit gecondenseerde melk, snoep, suiker, chocolade, en bonen. Er was vrijwel geen pakket zonder tabak of sigaretten.

\section{Bezorgduur}

Op elke kaart staan, zoals gezegd, de data van verzending, ontvangst en de retourbevestiging. Na bestudering van zo'n 60 kaarten kan worden geconcludeerd dat een zending minimaal één en maximaal drie maanden onderweg was.

\begin{tabular}{|l|l|}
\hline Aschach* & Aszód \\
\hline Braunau* & Boldogasszony \\
\hline Havelberg* & Budafok \\
\hline Frankfurt am Oder* & Czeglédi \\
\hline Heinrichsgrün* & Gyoengyoes \\
\hline Nagymeger* & Jászárokszállás \\
\hline Parchim* & Katzenau \\
\hline Soltau* & Königsbrück \\
\hline & Nezsider \\
\hline
\end{tabular}

Tabel 3: Overzicht van de Duitse en Oostenrijk-Hongaarse kampen

Van de kampen met een ${ }^{*}$ is bekend dat er pakketten zijn ontvangen door Servische gevangenen. Op basis van het beschikbare materiaal kan worden gesteld dat ook Serviërs in de andere kampen hulp hebben ontvangen van Liefdewerk.

\section{Nawoord}

Wat kan men zeggen? Over de Nederlandse steun aan de Serviërs in OostenrijksHongaarse en Duitse kampen is slechts weinig bekend, maar de steun was wel van onschatbare waarde voor hun morele overleving.

Dit artikel is een bescheiden eerbetoon en blijk van dankbaarheid aan Nederland en de organisatie Liefdewerk.

Dank aan Peter Poortvliet, Hans Kremer en Hans van Lith voor de vruchtbare discussies en bijdragen. Speciaal dank aan Marleen Poortvliet voor het omwerken van mijn Nederlands naar het 'Algemeen Beschaafd Nederlands'. 


\section{Literatuuropgave}

Dietz, H. Privatna komunikacija

Holleman H. 2014. 'Internering van buitenlandse militairen in Nederland gedurende de Eerste Wereldoorlog. Nederlandse Vereniging van Poststukken- en Poststempelverzamelaars. Arnhem.

Kremer, H. 2014. 'Dutch Charity in Maastricht during WWI.' Netherlands Philately $39,(2 / 2014)$.

Kremer, H. 2014. 'Nederlandse Liefdadigheid in Maastricht in de Eerste Wereldoorlog.' Digizine 't Fak Tuweeltje 39, (4/2014).

Lith, H.van. 2011. Twee miljoen pakketten. Soesterberg: Aspekt.

Milojević M. 1994. Balkanska ravnoteža. Beograd: Signature.

Notermans,J. 2015. Liefdewerk en pakketten uit Maastricht. Maastricht.

Radojević M., Dimić Lj. 2014. Srbija u Velikom ratu 1914-1918. Beograd: Srpska književna zadruga, Beogradski forum za svet ravnopravnih.

Radovanović, Milan. 2017. Holandsko „Milosrde“ i Srbi Velikom ratu (1916-1918) Nemi svedoci. Beograd.

Steen, P. van der. 'Schampschot: een klein Nederlands dorp aan de rand van de Groote Oorlog.' Amsterdam: Balans.

\section{Internetbronnen}

Prvi svetski rat. Logori za Srbe u Austrougarskoj. preuzet <20. 02. 2018>; dostupan preko $<\mathrm{http} / / /$ prvisvetskirat.wikidot.com/logori-za-srbe-u-austrougarskoj>

International Encyclopedia of the First World War. preuzet <20. 02. 2018>; dostupan preko <http://1914-1918-online.net $>$ 